in her short journey up country with Mr. Bock, she, being an intelligent child, picked up a few words of Laos; the joints of her arms and fingers possess, it is true, accurding to European ideas great flexibility, but really they have it to no greater degree than those of ordinary Siamese ; it is also true that she is able to use her toes, grasping things between the big toe and the next one in a way that is surprising and amusing to Europeans, but this is a faculty which all Siame:e, being a barefooted people, possess to a greater or less degree ; the child was losked upon here as even a greater natural curiosity than she is considered to be in. England, her parents being in the habit of taking her about and showing her for a small reward, and the price they obtained for her (in native currency equal to $60 \%$.) being twice that of an ordinary child of the same age. A strange mistake has been made about the child's name, "Krao " being merely the Siamese name for whiskers, a very natural nickname for the clild to obtain. As far as I can ascertain from those who knew the child well, she is endowed with the average intelligence of Siamese children of her age and class, and beyond her abnormal hairiness presents no peculiarity.

To sum up, "she is," as you rightly remarked, " merely a lusus natura, or a sport, possessed rather of a pathological than an anthropological interest. I may add that I have carefully verified all the foregoing statements.

A RESIDENT

Bangkok, Siam, March 3

[From information that has si ice reached me I am able fully to confirm the particulars here supplied by "A Resident." A. H. K.]

\section{Singing, Speaking, and Stammering}

In NATURE, vol. xxvii. p. 532, in the report of Dr. Stone's lecture on "Singing, Speaking, and Stammering," there appears a Classification of Vowels, which is described as an abstract of Mr. Melville Bell's scheme. I shou'd like, however, to point out that the system which $\mathrm{Mr}$. Bell has advocated for the last fifteen years is hardly re,resented in the Classification referred to. On turning to p. 63 of Mr. Bell's "Souads and their Relations," which is a new exposition of "Visible Speech," it will be seen that the vowels $I r$ and $A h$ are not described as labio-lingual, and that the threefol 1 arrangement of the vowels as lingual, labio-lingual, and labial is abandoned as incorrect. The lecturer does not appear to have mentioned the phonetic researches of Mr. A. J. Ellis and Mr. Henry Sweet. In many important points, however, they supplement the system of Mr. Bell, and their works cannot be overlooked in the scientific study either of etymology or pronunciation. The student of language can hardly do better than begin with Mr. Ellis's "Speech in Song," and Mr. Sweet's "Handbook of Phonetics."

5. Alexandra Road, Wimbledon, S.W., April 10 JAMES LECKY

THE classification of vowels to which Mr. Lecky refers is taken fro.n Mr. Melville Bell's "Principles of Elocution," which I obtained with much difficulty from a publisher in Salem, Mas:achusetts. It is dated 1878 , and may, I suppose, be held to represent the author's system at that date. I am well acquainted with the other works named by Mr. Lecky. W. H. STONE

As an illustrative instance of the peculiarities akin to stammering, referred to in Mr. Stone's lecture in last week's NATURE (p. 559), I may mention the case of an old Scotch lady whom I knew some years ago, and who was in the habit of interpolating at frequent intervals in her talk the wholly irrelevant words "This that here there ye ken." She herself evidently made $u$ e of the words with perfect unconscionsness of their irrelevancy; indeed I doubt whether, if challenged, she would have admitted using them at all.

$\mathrm{K}$.

\section{A Curious Case of Ignition}

"A Curious case of iznition," quoted in NATURE, vol. xxvii. p. 509 , reminds me of a similar circuinstance that came under my own observati n when serving in H.M. despatch vessel Psyche, 1862-66. We were moored "head and stern" in Port Napoleon, Marseilles, on a bright summer day. A strong smell of burning was traced to the saloon skylight. On bursting open the door of the saloon it was found that a scuttle glass (a planoconvex lens) through which the solar rays were admitted and focused on a rep curtain (which was smouldering) had been substituted for a broken one, but through an oversight had not been ground on the plane surface (as is usual). The case was reported by letter, and an order issued to in ure all scuttle glasses used in men-of-war for the purpose being ground.

BERTRAM GWYNNE

\section{Fibreballs}

I HAVE seen balls of vegetable fibre, such as those referred to by Mr. G. H. Darwin in his letter of March 23 (NATURE, vol. xxvii. p. 507), in great abundance on the sea-beach a Cannes; there however they are not spherical like those described by Sir A. Musgrave, but cylindrical, two or three inches in lengtb, finely and closely matted, and all wonderfully similar in appearance. In one place they had been collected and employed, if I remember rightly, to form a kind of wall. Some balls of a similar kind, but more nearly spherical and much coarser in texture, were found, on draining a pond, by Dr. Fitton, and sent by him to Sir J. Herschel, these were three or four inches across, and looked almost llke small hedge hogs rolled up.

F. H.

\section{Benevolence in Animals}

Mr. Geo. J. Romanes, in a lecture delivered in Manchester, March 12, 1879, on "Animal Inteligence," points out the following emotions which resemble human intelligence as occurring in animals below the human species, namely : fear, affection, passionateness, pugnacity, jealousy, sympathy, pride, reverence, emulation, shame, hate, curiosity, revenge, cruelty, emotion of the ludicrous, and emotion of the beautiful, and gives some remarkable instances in support of his statement. To this I can add benevolence on the part of our household cat, who was ob served to take out some fish bones from the house to the garden, and, being followed, was seen to have placed them in front of a miserably thin and evidently hungry stranger cat, who was devouring them; not satisfied with that, our cat returned, pro cured a fresh supply, and repeated its charitable offer, which was apparently as gratefully accepted. This act of benevolence over, our cat returned to its customary dining-place, the scullery, and ate its own dinner off the remainder of the bones, no doubt witb additional zest.

Woodend, Fortis Green, N., April 12

\section{The Zodiacal Light (?)}

LAST Friday evening about 7 p.m. my attention was called to a peculiar appearance in the western sky. The sun had set not long before. No clouds were visible but one long thin streak, and there were the usual mists near the borizon. Abjve where the sun might be, a pillar of light faintly red in colour, with sof edges, but fairly well define $d$, rose vertically from near the horizon to the height of perhaps a few degrees. It did not look like an illuminated cloud nor like rays of light shot up through a cloud, nor like anything local ; in fact I am told that it moved north. wards with the sun. Was this the zodiacal light, or merely some sunset effect? It began to grow dim about 7.10 p.m, but was visible later than this.

New Kingswood School, Lansdown, Bath, April io J. W. B.

\section{Braces or Waistband?}

THE writer has for the last thirty years dispensed with the use of either braces or a belt, having had his waistcoats made with short elastic straps attached inside and with holes to button on to the trousers like braces, one on each side and a third in front.

They answer as well as braces in conjunction with the ordinary waistband and buckle of the trou ers, and the wearer is saved the feeling of strain across the shoulders or round the waist con. nected with the use of braces or a belt.

G. H. April I3

\section{THE TEACHING OF ELEMENTARY $M E C H A N I C S^{1}$}

$A T$ the recent Annual Meeting of the Association for A the Improvement of Geometrical Teaching held, as has already been noted in our columns, at University I Association for the Improvement of Geometrical Teaching, Ninth General Report, January, 1883. 